\title{
Considering international mobilities in the light of the places they produce. Avenues of reflection based on religious tourism (Israel, the United States, Europe)
}

Penser les mobilités internationales à l'aune des lieux qu'elles produisent. Pistes de réflexion à partir du tourisme religieux (Israël, États-Unis, Europe)

Pensar las movilidades internacionales en relación con los lugares que producen. Vías de reflexión a partir del turismo religioso (Israel, Estados Unidos, Europa)

\section{Caroline Rozenholc}

Translator. Riad Tacherifet

\section{OpenEdition}

\section{Journals}

Electronic version

URL: https://journals.openedition.org/remi/10329

DOI: $10.4000 /$ remi.10329

ISSN: $1777-5418$

This article is a translation of:

Penser les mobilités internationales à l'aune des lieux qu'elles produisent. Pistes de réflexion à partir du tourisme religieux (Israël, États-Unis, Europe) - URL : https://journals.openedition.org/remi/8969 [fr]

\section{Publisher}

Université de Poitiers

\section{Printed version}

Date of publication: 1 December 2017

ISBN: 979-10-90426-60-3

ISSN: 0765-0752

Electronic reference

Caroline Rozenholc, "Considering international mobilities in the light of the places they produce.

Avenues of reflection based on religious tourism (Israel, the United States, Europe)", Revue européenne des migrations internationales [Online], vol. 33 - $n^{\circ} 4$ | 2017, Online since 01 December 2018, connection on 14 April 2022. URL: http://journals.openedition.org/remi/10329; DOI: https://doi.org/10.4000/remi. 10329

This text was automatically generated on 14 April 2022.

(C) Université de Poitiers 


\section{Considering international mobilities in the light of the places they produce. Avenues of reflection based on religious tourism (Israel, the United States, Europe)}

Penser les mobilités internationales à l'aune des lieux qu'elles produisent. Pistes de réflexion à partir du tourisme religieux (Israël, États-Unis, Europe)

Pensar las movilidades internacionales en relación con los lugares que producen. Vías de reflexión a partir del turismo religioso (Israel, Estados Unidos, Europa)

\section{Caroline Rozenholc}

Translation : Riad Tacherifet

\section{Introduction: When mobilities re-examine the issue of place}

This research note intends to revisit the first theoretical and methodological avenues that emerge from an ongoing research on what shall be referred to as international religious "places of mobility" (Barrère and Rozenholc, 2018). This research focuses on the combined socio-spatial effects of pilgrimages and religious tourism in places where these mobilities converge. By regarding pilgrimages and religious tourism as two modalities of one single "religious spatial undertaking", this research comes in the wake of authors such as Chiffoleau (2003), Park (2004) and Ron (2009) who compare these two types of mobility. It also falls into a field at the crossroads of the geography of mobilities and religious social sciences. This field, undergoing structuring in France, has been fostered over the past few years by work on migrations (Bava, 2005; Bava and Capone, 2010), as well as on pilgrimage (Bennafla, 2005; Chiffoleau, 2003 and Chiffoleau 
and Madoeuf, 2005) or on religion's spatial dimension (Dejean and Endelstein, 2013; Trouillet 2013 and 2015), political (Aubin-Boltanski, 2003 and Adelkhah, 2007) or transnational (Argyriadis and al., 2014 and Capone, 2010). The current research differentiates itself, however, by only taking into account international religious mobilities- the idea being to understand the role of international actors in the production of places and eventually be able to extend the reflection to local effects of international mobilities in general ${ }^{2}$, interpreted in the light of the places they "produce", and not of a population or a given group of actors. Production being understood here as per Lefebvre (2000) meaning the combination of practices, conceptions and perceptions, the term can refer to the construction, as well as the destruction or the transformation of places in time; places studied with a dynamic and inclusive approach and less from the perspective of duration and anchoring.

2 This change of perspective shows what is at stake with the notion of place, its role in the city, and what makes or can make a place in the $21^{\text {st }}$ century in a world of seemingly exponential flows of pictures, information and people: be they commuting, tourist, religious, migratory mobility, or exile. Indeed, this generalised circulation, whether chosen or not, has augmented and sometimes contradictory practices and presences collide in an unprecedented manner in places. A polymorphic reality and polysemic notion if any, the place actually appears today more than ever as an entanglement of practices, a kaleidoscope of experiences, of strata, of multiple memories and simultaneous events (Rozenholc, 2010). How can it subsequently be defined? The place is first of all a material form - a dense, open, but defined form (Schnell, 2007) - and it is in this that, for example, it distinguishes itself from the notion of territory in geography. A significant portion of space, the place conveys a centrality, a historical depth and is endowed with a strong inspiring capacity. The place thus offers grips for action (as per Joseph, 1992 and 1997) and for multiple identity narratives. Another specificity of the place is that it has no dimensions or boundaries a priori although it remains associated to the local and even micro-local scale of phenomena. However, other scales are active within it and develop locally, proceeding in scale "leaps" (Smith, 2004; Schnell, 2007). The place also defines itself by the interactions and the social practices that occur and consequently by the atmosphere that ensues.

3 The social and emotional dimension is particularly present in English language literature on place through the idea of sense of place that distinguishes space from place in identity building. Geographer Schnell (2007) goes further by maintaining that the atmosphere has henceforth replaced "authenticity" in the definition of the places (Relph, 1976). Made up of different qualities and presence modes, the atmosphere is what would give today their consistency to places that everyone has experienced differently. Thibaud (2004) sees it as an indicator, a "rhythm" that explains the inspiring and transformative power of the places, particularly acute in the places associated with religion. The discrepancy between this definition of places- that could be summed up by "places, in themselves, are manifold" and the one given by Foucault (1984) (places are "locations" irreducible one to another) indicates the profound transformation the place and the relation with the place have gone through for thirty years. 


\section{Considering the plurality of places and their multidimensionality}

4 Starting from this definition of the place and acknowledging its intrinsic plurality, this research proposes to study the materiality of places and the practices they induce or allow. Three dimensions are chosen to this end in order to determine the depth, the significance and the meaning of contemporary places: the temporal, material and socio-political dimensions. Taken together, these three dimensions contribute to the development of a sensitive geography (Rozenholc, 2010) thanks to which one may understand the dynamics as well as the actors that build and transform places over time, the way these physical transformations take place and the role of international visitors in their physical and symbolic production.

5 The first of these dimensions is the temporal dimension of places. It stems from three aspects. Firstly, places have a geohistory, a depth that can be interpreted thanks to traces and marks (Bulot and Veschambre, 2006) - posters, banners, graffiti, shops names, but also, ruins or urban wasteland. These "details" (Piette, 1996) either tenuous or clearly visible, incorporated by successive or simultaneous presences, are strong vehicles for identity and identification to the place that require being taken into account. Then, the temporal dimension of places also stems from their gradual transformation: far from being fixed, places are in constant evolution. Finally, the temporal dimension enables one to consider the temporality of customs and presences in the places studied. In the case of peregrine mobilities we are dealing with here, several specificities can be noted. These specificities are occasional; they operate according to specific agendas and put into motion, over the same routes and with similar gestures, individuals that are at first glance always different.

6 The second dimension considered is the material dimension of places. It raises other issues. Two will be addressed. The first one is that of the form however little discussed by geographical literature on the place that mostly focuses on social practices (Buttimer and Seamon, 1980; Debarbieux, 1995; Massey and Jess, 1995; Monnet, 1998; Piveteau, 2010). Yet, it has been said that the place is first a form with a structure, an architecture, but also (a crucial point) an internal organisation made up of thresholds, continuity and ruptures, of boundaries and with a porous nature as addressed by Bonnin (2010), for example. The second issue is that of the producers of these concrete forms, private or public entrepreneurs, architects, urban planners who design or revamp existing places in order to meet or even anticipate the needs of pilgrims and religious tourists. Who are these producers and how do they work in places, such as religious themes parks that are seeing the light of day these days?

7 The third dimension, transverse to the other two, is the socio-political dimension. It enables one to question what is at stake socially and politically "in" places that, particularly in places of religious mobilities, bring together individuals and collectives whose paths and mobilities but also practices and interpretations of the places are distinct, conflicting or shared as it is the case for "mixed or ambiguous" places of pilgrimage, shared by several religions (Albera, 2005). This dimension then raises the issue of public authorities and bodies that govern the places visited organising the joint presence. It also raises the issue of the action directories involved in each individual's interactions. 

place today and enables one not to be limited to a population or to a type of actors in places that are by definition pluralist.

With this approach, their combined effects on the places visited can be understood and everyone's role in their symbolic and material production can be clarified. It requires, according to what field study shows, being interested in types of places of eminently different scope and meaning. Therefore, comparing places of pilgrimage, substitute places and religious theme parks looked will enable the update of the hypothesis that this research borrows from Halbwachs (2008 [1941]) in his work Topographie légendaire des Évangiles en Terre sainte, of places shaped in response, by successive back and forth movements of material and symbolic elements. They will also provide food for thought regarding the paradoxical nature of places (Debarbieux, 1995) that stems from their location and their specific attributes, but also from their situation in dependencies involving other places.

\section{Of the production of three types of places through international religious mobilities}

10 Polysemic and paradoxical, at times drawn on, sometimes neglected, it is at any rate taking French language literature a long time to formalise the notion of place. It is however making a strong comeback, particularly in the work on international mobilities and on transnationalisation of religion (Argyriadis et al., 2014; Capone, 2010) that emphasises its increasing importance in practices. This work also highlights, without however dealing explicitly with it, the place's dual dimension, as a source of anchor an as a medium for mobility (Imbert et al., 2014). The current context therefore sees resorting to the place as the fundamental support to the human person, what Dardel (1990) used to call "geographicity", amplify while at the same time the place is becoming more complex. It is claimed by "social movements that are either communitarian, regionalist, nationalist, environmentalist, progressive (globalist and at the same time localist), atavistic, conservative, or even reactionary (Entrikin, 2003). Urban studies on heritage show for their part, an escalation of memory claims rooted in places of identification and of recognition; an interest that also is testament to a renewed attention for sensitivity and experience in a globalisation that segments sociospatial affiliation (Lahire, 1998).

11 Questioned on "how is religion fertile ground for a reflection on the place", Piveteau (2010) answered he had been struck, each time he addressed "this issue on the borders of geography and religion, to notice a huge shortcoming" without, however, being able to explain "what particularises the heuristic interest of religion as a purpose or an authority regarding the relation to the place. It is this difficult question this research wants to contribute to on the basis of the equation between place, mobilities and religion since it reveals the force of attraction, of convergence and of transformation of places. Transformation of those who experience it - it is the stated goal of pilgrimageand transformation of the places over time. It is a dynamic approach that combines the idea of places constantly being (re)produced, by a multitude of actors, and part of networks that go beyond their mere local issues. Interpreted in the light of religious mobilities, places thus appear as located realities, but that do not only amount to one 
scale or territory. On the contrary, they are testament to the linkage between local, regional and national situations whose connections need examining.

On this issue, the Israeli-Palestinian space offers a particularly stimulating laboratory. Religion is pervasive and its effects on space particularly structuring. Besides, religious tourism places are numerous and diverse with Christian, Muslim, Jewish, Baha'i and Druze places of pilgrimage. That being so, if one follows the proposal of Halbwachs (2008 [1941]), the local dimension of places of pilgrimage does not suffice to understand them. He shows, on the basis of Christian holy places, that the latter also need to be considered in terms of exchanges and of back and forth movements towards other places and therefore other actors. He provides the example of the Via Dolorosa and its "replicas" that were thriving in Europe from the $14^{\text {th }}$ century on. These supplementary Stations of the Cross enable those who wish to to "make the Jerusalem pilgrimage" without actually going to the Holy Land. The subtlety and the interest of Halbwachs' demonstration lie in showing that the original places eventually tend to gradually conform, to align with their replicas. He gives the example of the Great Journey and Recollets' Calvary of Romans in the Drôme. Conceived in 1516 by a merchant of the region upon his return from Jerusalem, it consists of fourteen stations in the townwhose topography reminded those who were coming back of Jerusalem's- and leads to a cavalry beyond the walls. A chapel and a convent were eventually built then seven other stations. Abandoned in the $19^{\text {th }}$ century, it has now become a place of devotion and pilgrimages again. It has in addition been classified as a historic monument since 1986.

13 Often mentioned by heritage and memory studies specialists, the way in which it offers a three-way triangulation between the original, the replica and the compliant original is also a great wealth for geographers who are interested in the effects of international mobilities. These replicas, built by pilgrims upon their return from Jerusalem, actually represent very concrete instances of the production of places through international mobilities. Reproductions necessarily inaccurate, they show to what extent the discrepancy between a place and its representations does not negate the appeal of the latter; some being themselves major places of pilgrimage and/or subject to international recognition when they are UNESCO World Heritage sites. It is the case of two Slovakian and Polish cavalries that have dimensions, effects on the reshaping of their environment and an unequalled international influence. As the one in Romans, they enable a very concrete approach of the material production of places through religious international mobilities and a comparison, not as much of their shapes as of the processes that ruled over their establishment and their development. The first one, the Banská Štiavnica (Slovakia) Mount Calvary was built between 1744 and 1751. It has been selected here for its size: with twenty-four stations (ten more than in Jerusalem), it is one of the largest Cavalries in Europe. The second one is the Kalwaria Zebrzydowska, in Poland, located forty kilometres from Cracow. It is one of the most visited places of pilgrimage in Poland. Its construction, begun in 1601 with a chapel dedicated to the Crucifixion on the model of the Holy Sepulchre in Jerusalem, spanned two centuries, with thirty-nine other chapels. In addition to these forty chapels, there are also a basilica and a convent that, together, review the whole topography of the place. The hills were rechristened Golgotha, Mount of Olives, Zion, Moriah and the Skawinka River serves as Kidron. These two cavalries have been included on UNESCO's World Heritage list since 1993 and 1999. 
Today, almost eighty years after Topography was published, other places question anew these joint productions and back and forth movements between places. How do things stand, for example, regarding Christian religious theme parks that also reproduce, in a more dramatised fashion, the Holy Land and Jesus's life? Can they be thought out according to this same dialectic of places? To whom and how are they intelligible? Some are ancient, some really recent. There is first of all the Palestine Park built in the state of New York in the 19th century and rebuilt several times since. It is home to a one hundred meter replica approximately on the Holy Land's scale. Lake Chautauqua serves as the Mediterranean Sea, so that landing from a ship in Palestine Park at the time enabled visitors to set foot in the Holy Land. Then there is Holy Land Experience opened in 2001 in Orlando, "a biblical amusement park" that establishes itself as a place to see (with the largest ancient Jerusalem model or the Jesus Boat, the reproduction of a Lake Tiberias fisherman's boat) and a place to experience with a market hosted by merchants in period attire, the opportunity to take part in Jesus's last supper, and even more surprising, musicals and a 3D reconstitution of the crucifixion. There is finally the Ark Encounter that opened in 2016 in Kentucky and offers a "life-size" reconstruction of Noah's Ark (three bridges, 155 meter long and sixteen meter high) and a so-called exotic zoo. Not without controversy ${ }^{3}$, this type of project is multiplying in the UnitedStates, but it has also spread to Israel with the opening of a Nazareth Village in 2000 right in Nazareth and to Europe with the project of a Holy Land Park in Majorca and of a Centrum Polonia in Tertio Millennio in Poland.

Nazareth Village is particularly interesting to study not only because being halfway between an outdoor museum and a theme park, it is situated in Nazareth, one of the centres of Christianity, but also because Christian Arabs play the part of Jewish characters contemporary of Jesus. Feldman and Ron (2011) link its creation to what they call the Americanisation of the Holy Land by Protestant pilgrims. Nazareth Village stages a farm and a village from the first century AD to "present the life, the time and the teachings of Jesus of Nazareth to the whole world"4. Its objective is to provide tourists with the opportunity to "experience and see the time and the life of Jesus". A first analysis of the comments posted on the Internet by visitors suggests that the experience offered by the Village meets a certain demand and certain expectations of "authenticity" unmet with the visit of today's Holy Land. The term may be surprising regarding a place that imitates for commercial purposes a reality that has disappeared, but it must be understood within a modern context where the atmosphere of the places, the pace and the practices of Jesus's time (which the pilgrims are also seeking) are difficult to perceive after 2000 years of urbanisation. Is it consequently, in these places that combine religious experience, tourism, economic and even recreational dimensions, an additional, supplementary experience to the pilgrimage or more broadly to the experience offered by the holy places? 


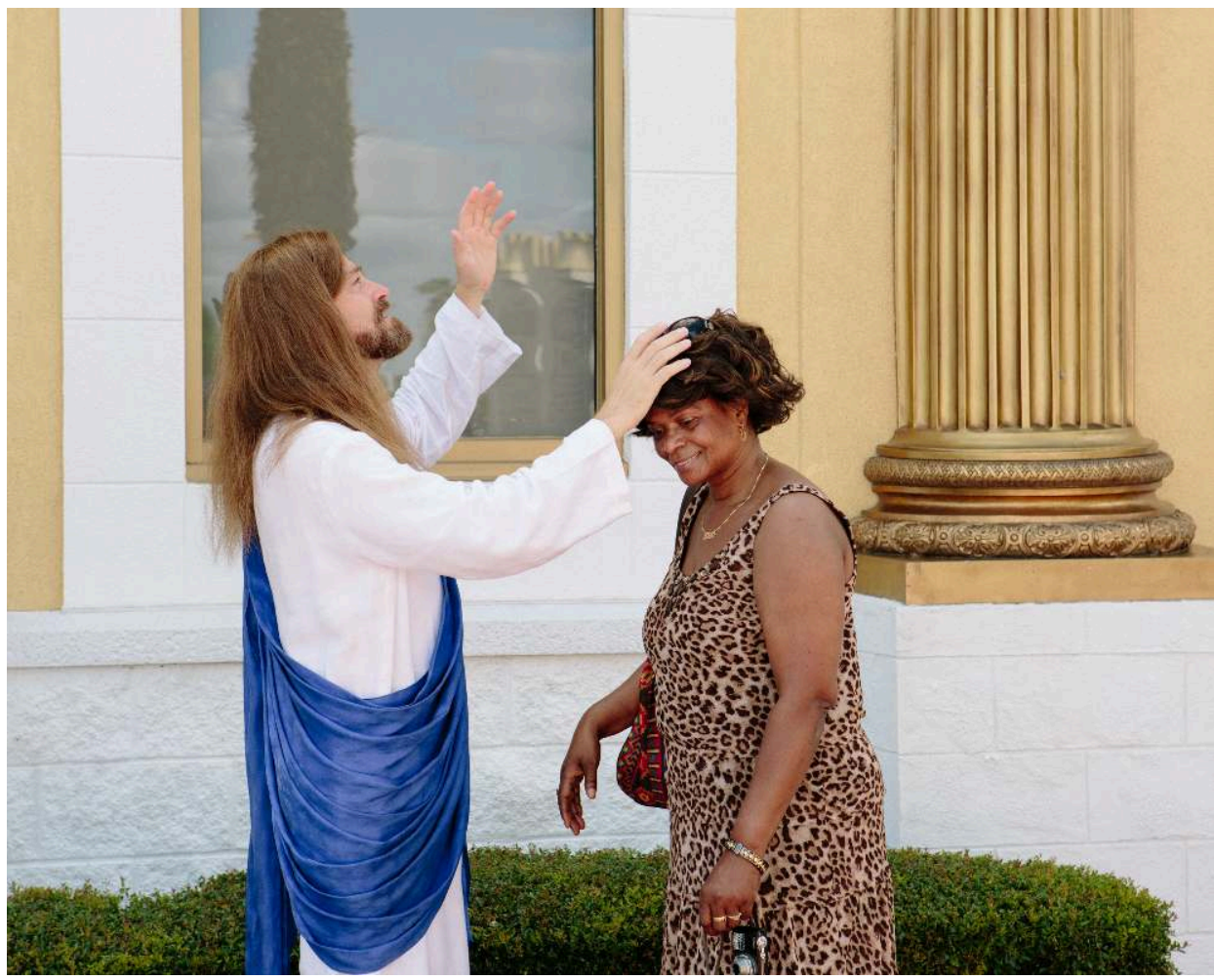

A woman is asking the actor who plays Jesus at the Holy Land Experience to bless her.

Source: http://cnnphotos.blogs.cnn.com/2014/01/24/jerusalem-florida-the-holy-land-experience/ Credit: D. Cronin.

\section{A pluralist ground to study the spatial effects of international mobilities}

16 If this research calls for the structuring of a pluralist ground, through the types of spaces studied as well as their national context, it is focused however on the IsraeliPalestinian space. How can this space that is given particular media attention and is roughly divisive be described? It is firstly a space profoundly structured by several decades of conflict, the failure to resolve it, its pervasiveness and by recurrent episodes of open warfare. The conflict- through its duration and its identity-related dimensionpervades all aspects of the social, political, economic, territorial and urban life, and this whatever the actors and spaces. Besides, it is a space organised around major oppositions. If the most obvious one uses the state categories "Jews" and "Arabs", one must underline the growing polarisation, in Israel, between religious and lay, between new and old Jewish migrants and between Ashkenazi and eastern Jews, those originally from Maghreb countries and from the Middle East (Iran, Iraq, Yemen, Morocco for example).

These categories, and the way they are realised spatially, stem from the country's creation through the exile of hundreds of thousands of Palestinians as of 1948 and the reception of successive waves of Jewish migrants carried by a political, territorial and legislative project. Thus, thanks to the 1950 Law of Return, hundreds of thousands of migrants arrived in Israel after the decolonisation of North African and Middle-Eastern 
countries and nearly 1 million migrants from the former USSR swarmed in after the break-up of the Soviet Bloc. These figures explain why fifty years after the creation of Israel, $40 \%$ of the Jewish population was still born outside the country (Yishai, 1999).

As for religious mobilities, the Israeli-Palestinian space is characterised by flows that are dense, as well as multidenominational and multipronged. There are, on the one hand, outbound flows of Jewish Israeli pilgrims towards Morocco and Ukraine and Muslim towards Saudi Arabia and on the other hand, inbound flows of Jewish, Christian, Baha'i, Druze, Muslim pilgrims that converge in Jerusalem and Galilee. Cospatiality in this type of spaces gridlocked with religion and distinctive practices where strong social distance is commensurate with intense spatial proximity ${ }^{5}$ - is exemplified by the Via Dolorosa, the first of our grounds.

It is a route, about 500 metres long, that leads Christian pilgrims coming from all over the world, from a Muslim quarter to a Christian quarter in Jerusalem's old town, the disputed capital of the Hebrew state also claimed by the Palestinian Authority. It then reaches the Holy Sepulchre basilica whose management is regulated by an 1852 Ottoman decree. There are stations along the way (fourteen today, seven in other periods), that are reminders of the episodes of Jesus's passion, as well as holy places and churches, some of which were built by France in the $19^{\text {th }}$ century (the Church of Saint Peter in Gallicantu and the church of the fourth station (Trimbur, 1998). While this space appears as eminently "local" and as if it were fixed or immutable, its fixing actually only took place when it was sought to match Jesus's stops to the place of his crucifixion (Golgotha/Holy Sepulchre) with the stations conceived as early as the $14^{\text {th }}$ century by the Franciscans in their Holy Tour, then with the European Stations of the Cross (Halbwachs, 2008 [1941]). Thus the appeal of the Via Dolorosa lies in this fluidity of the place and in the multitude of actors that live there today side by side (foreign pilgrims and tourists, representatives of the various local or national authorities, shopkeepers, Palestinian inhabitants of the old town and an increasing number of Orthodox Jews. It particularly enables the study of the effects of pilgrimages on places that, though the holiest in Judaism, Islam and Christianity, are nevertheless both eminently tourist places and with an everyday life. Densely populated, it shows the interactions and the scenes provided by these places between daily users and visitors. How can Palestinian inhabitants and shopkeepers from the old town benefit from these tourist and religious flows and add value to what Retière (2003) calls their "autochthony capital"? 
Picture 2: The Via Dolorosa: the sixth station

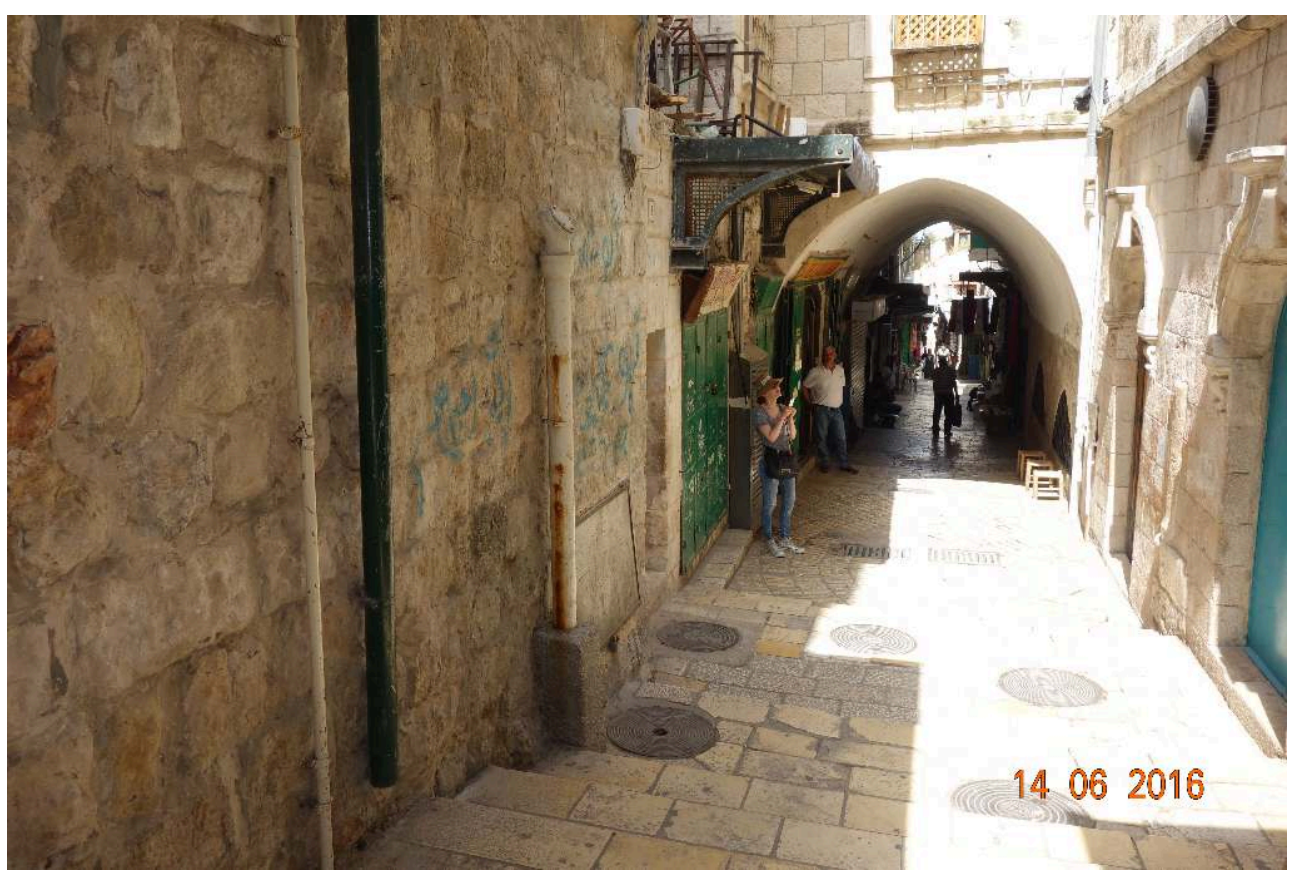

Usually very busy, the Via Dolorosa is almost deserted on this picture after several stabbings took place in Jerusalem's old town. The ground floors are occupied by shops- on the left and in the background-several of them being closed. The top floors are used for housing.

Credit: C. Rozenholc, June 2016.

After Jerusalem, the second focus of this research is Tiberias, the second destination of international pilgrims in Israel, but also a tourist hotspot. We are interested in Tiberias here as both a multidenominational and an international place of pilgrimage for Christians (who see it as the place of Jesus's "ministry" and miracles), Jews (who worship the grave of kabbalist rabbis such as Maimonides), and Druze (who venerate the graves of Jethro, Moses father- in-law, of Nabi Sabalan and of Nabi Yaafori). Therefore, it is the whole of the city and its surroundings that have been revamped by the tourist-religious industry. However, Galilee provides another place worth considering for its international attractiveness and its effects on space. It is the tombstone of the Bab, better known as the Baha'is gardens in $\mathrm{Haifa}^{6}$. In ruins in the 1930s, they were included, after several renovations and expansions, in UNESCO's World Heritage of Humanity in 2008. These gardens are terraced (nineteen terraces with an elevation difference of 225 metres) which is evidence of a particular care for symmetry, for the essences grown and for the materials used. Begun as early as 1910 and completed in 2001, this place rightly addresses the issue this research raises and is also an answer to the reflection about the interconnection between material and symbolic production through international mobilities, especially since tough the centre of Baha'i faith is located today in Israel, Israeli citizens cannot convert or belong to it. 
Picture 3: The Baha'i gardens on the north slope of Mount Carmel in Haifa

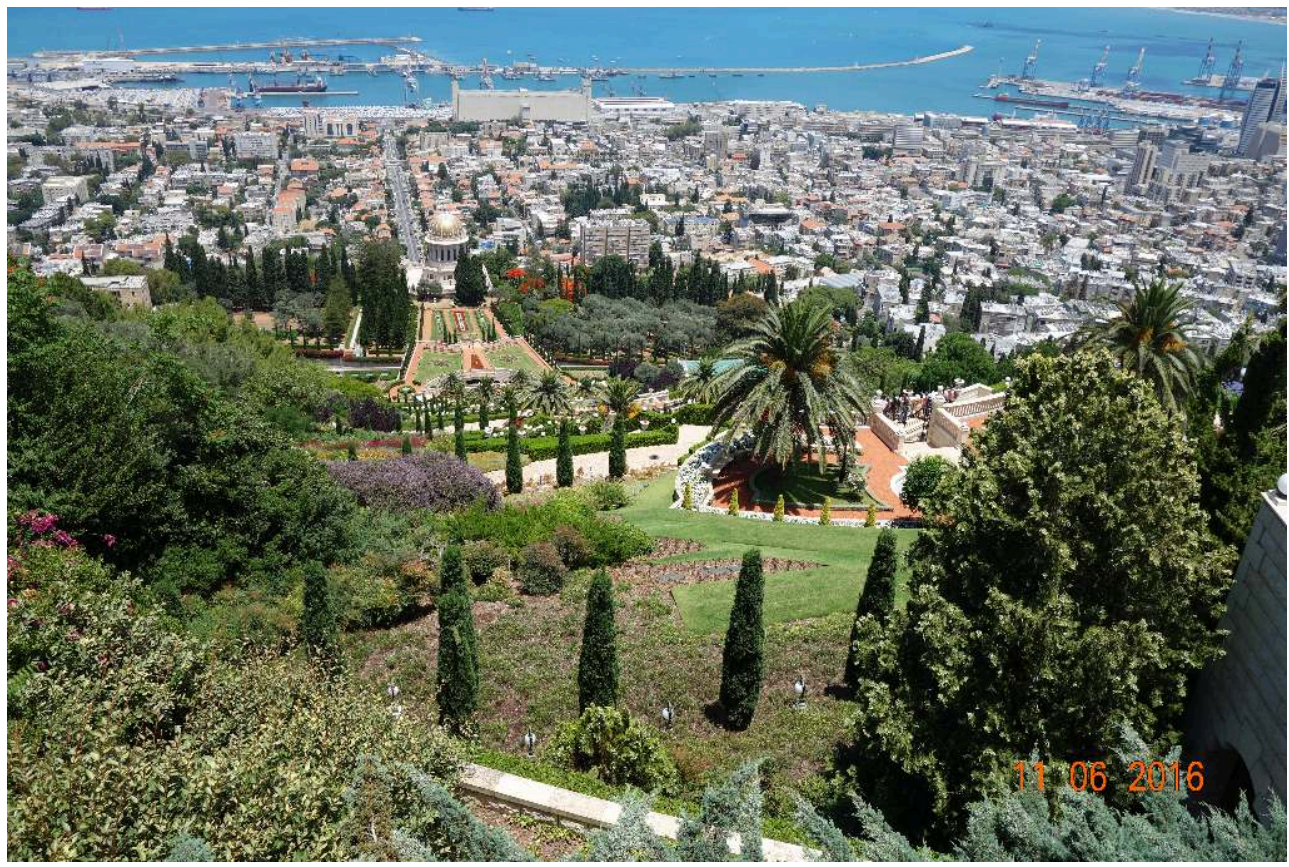

These twenty hectares gardens are a breath of fresh air and a major landmark in the city. The picture shows how their layout stands out from the rest of the city while being interwoven into it?

Credit: C. Rozenholc, June 2016.

\section{A methodological mechanism to analyse various types of places}

21 These grounds and types of places, distinctive by their meaning and their location, are nevertheless linked theoretically by the problematic of this research (the production of places through international religious mobilities) and, in practice, through the circulations that connect them and that will have to be disclosed. In order to achieve this, this research will borrow various tools from geography: standard quantitative analysis of mobilities (in order to contextualise, quantify and map religious mobilities), observation (in order to grasp the actors, but also the forms and the organisation of the spaces when they are empty and full), interviews (in order to understand the perception and the role of the various actors in the production of places) and internet and social media analysis (in order to comprehend the transnational dimension of these places and the way numerous pictures and narratives of these places are circulated). The goal of this methodological mechanism is threefold: the ability to be mobilised on several grounds, analyse jointly various types of places of mobility and enable several categories of people to interpret the places studied. This mechanism will allow an approach of places of mobility through their material, temporal and social dimension, by taking into account the diversity of flows, the temporality of pilgrimages and the multiplicity of actors that are, directly or indirectly, connected to them. Implemented that way, this system will allow the places studied to be compared, not one with another, but to bring to light the springboards and the processes of production through mobilities. 

variety of tools offered and in their combination in order to analyse the various places studied. If the most standard methods do not require here any particular clarification (quantitative analysis, interviews), this note is an opportunity to bring to light those that are the most innovative and particularly the one considered to "observe the places of mobilities", places with multiple functions (holy places, lively places, tourist places, commercial places) and with specific temporalities. In order to take this into account, these places will first of all be observed at various moments in the year: when they are over-crowded, as it is the case in Jerusalem at Easter, and outside pilgrimage periods, when there are few visitors. This observation will be carried out in particular thanks to photographs that will be used as observation and documentation tools of the situations, scenes, objects, actors and places of study. The places of mobility will for instance be photographed when they are "empty" and "full", with and without pilgrims, to show how their presence transforms the places and how their practices materialise. Photography will create a means of appreciation but also of comparison between the grounds.

Photography will also be used in interviews, particularly with the pilgrims and religious tourists from various religions and geographic origin ${ }^{8}$ to understand, on the one hand, the meaning and the priority they give to the places visited (by paying attention to the way they recount, describe their experience of the places and identify with them) and on the other hand, when it is the case, how they link up the various places visited. Some interviews will then be prolonged with discussions based on photographs of pilgrims and tourists on which the interview will then rest (Collier, 1957). Conducting interviews with interviewees using their own photographs will provide subjectivity that is not necessarily achievable during the interview and that is a key feature of the production of places. Besides, assuming that pilgrims participate in the production of the places they visit, paying attention to the pictures they make is important. These photographs will reveal (or not) a consistency with the iconography of the places of pilgrimage circulated on the Internet and will show how pilgrims and tourists recreate their journey through them.

observation of the places will also be conducted by following the proposal of architect and anthropologist Bonnin (2010), in order to better grasp the connections between the material and sensitive dimensions of places. His proposal, a largely formal interpretation, appears as necessary to understand what makes a place: the practices that materialise and the atmosphere that pervades. Besides, it encompasses the temporal, material and social dimensions that structure the questioning about the places at the heart of this research. To the study of the place through its depth and its surface, Bonnin adds the study of the style, the structure and the appearance of the places studied, but also of the architecture, of the dimensions and proportions of the buildings. He also analyses the internal organisation of the places by surveying the boundaries, borders, thresholds and circulations they enable or prevent. Finally, he analyses the way a place fits within its environment. This formal analysis, rarely conducted to address "the place", will allow an accurate description of the various places of study (whatever their type) and in doing so, the gathering of comparable insight as for the effects of forms on practices, atmosphere and meaning of the place. 


\section{Conclusion}

While the Israeli-Palestinian space is given particular media attention because of its political, territorial and religious tensions, its drawing force in terms of international religious mobilities is less known. Yet, they are at once diverse, in terms of geographic origin and religious affiliation, massive and recurrent. Every year nearly 3.5 million people (both pilgrims and tourists) visit the country; these are considerable figures considering the population that does not exceed 8 million inhabitants. By materialising both symbolically and spatially, they contribute to include the Israeli-Palestinian space in a transnational network, barely examined so far, of tourist-religious places: places of pilgrimage, places of substitution and theme parks where religion, merchandised and staged, nevertheless meets the expectations, in terms of experience and meaning of the place, of some pilgrims and religious tourists. In saying this, this research thus connects theoretically various types of places by granting them a distinctiveness to be analysed; that of "places of mobility". The implementation of the methodological mechanism will then show the drivers and processes of this construction in response to the places of mobility through material and symbolic exchanges of which pilgrims and religious tourists are, in a way, the vehicles: by experiencing places of pilgrimage, by reproducing them for them and where they live by substitution places, by circulating, to an even greater extent thanks to the internet, the pictures and narratives made of them or by seeking additional experiences in themes parks. Mirroring these types of places will provide a genuine breakthrough in the understanding of the place and of its production through international mobilities. It will also allow, according to Kong's suggestion (2010), the structuring of several scales of analysis of religions' spatial expressions: a micro one for the experience, a meso one for the production of the places and a macro one for the international or transnational relations. Thanks to the structuring of these three scales the Israeli-Palestinian ground will not be singled out and some of its aspects and actors will be revealed- in particular these international pilgrims who are neither Israeli nor Palestinians- and not concealed as they usually are in a way by the pervading politics and the conflict that prevails.

If in literature it is recognised that pilgrimages transform pilgrims, this research suggests changing perspective to try and understand how international religious mobilities produce and transform the places where they materialise. Questioning the places through religious mobilities will thus mean, on the one hand, comprehending the various actors- although they might not all have the same view- who co-produce them materially and symbolically. It will mean on the other hand, genuinely focusing on the spatial forms in which these experiences fit, on the meaning, and even on the atmosphere or the "spirit of the places" (Lévy et Lussault, 2000), they contribute to produce. By questioning the material and symbolic production of places through international religious mobilities, this research's aim is to better understand the production of the contemporary place and its meaning in a world where mobilities take up an unprecedented position. From this point of view, taking the place as a starting point offers the opportunity not to focus on one space, one population, or a specific group, to take into account a whole set of actors. Thanks to this staging approach (Goffman, 1973), narratives or paths can be apprehended, as well as the accumulation of practices and the temporal thickness, but also the dynamics of the places (Racine et Walther, 2003), while detaching oneself from singular spaces. 
In conclusion, once this research is completed, it will offer a renewed analysis of the Israeli-Palestinian space thanks to analysis categories - international religious mobilities- different from the pervading political one, but it will also allow theoretical and methodological breakthroughs on the issue of place and mobilities. Pilgrimages and religious tourism, barely addressed by geography despite the importance of the mobilities they generate, are strong elements of comprehension of the production and of the relation to the contemporary place.

\section{BIBLIOGRAPHY}

Adelkhah Fariba (2007) Économie morale du pèlerinage et société civile en Iran : les voyages religieux, commerciaux et touristiques à Damas, Politix, 77, pp. 39-54.

Albera Dionigi (2005) Pèlerinages mixtes et sanctuaires « ambigus » en Méditerranée, in Sylvie Chiffoleau et Anna Madoeuf Éds., Les pèlerinages au Maghreb et au Moyen-Orient. Espaces publics, espaces du public, Beyrouth, Presses de l'Ifpo, pp. 347-378.

Andézian Sossie (2010) Formation des identités palestiniennes chrétiennes. Églises, espace et nation, Archives de sciences sociales des religions, 149, pp. 189-210.

Argyriadis Kali, Capone Stefania, De La Torre Renée et Mary André (Éds.) (2014) Religions transnationales des Suds. Afrique, Europe, Amériques, Louvain-la-Neuve, L'Harmattan-IRD, 258 p.

Aubin-Boltanski Emma (2003) La réinvention du mawsim de Nabî Sâlih. Les territoires palestiniens (1997-2000), Archives de sciences sociales des religions, 123, pp. 103-120.

Barrère Céline et Rozenholc Caroline (Dirs.) (2018) Les lieux de mobilité en question. Acteurs, enjeux, formes, situations, Paris, Karthala, $184 \mathrm{p}$.

Bava Sophie (2005) Variations autour de trois sites mourides dans la migration, Autrepart, 4 (36), pp. 105-122.

Bava Sophie et Capone Stefania (2010) Religions transnationales et migrations : regards croisés sur un champ en mouvement, Autrepart, 4 (56), pp. 3-15.

Bennafla Karine (2005) L'instrumentalisation du pèlerinage à La Mecque à des fins commerciales, in Sylvia Chiffoleau et Anna Madœuf Éds., Les pèlerinages au Maghreb et au Moyen-Orient, Beyrouth, Presses de l'Ifpo, pp. 193-202.

Boivin Michel et Delage Rémy (2010) Benazir en odeur de sainteté. Naissance d'un lieu de culte au Pakistan, Archives des sciences sociales des religions, 151, pp. 189-211.

Bonnin Philippe (2010) Pour une topologie sociale, Communications, 87, pp. 43-64.

Brochot Anne et De La Soudière Martin (2010) Pourquoi le lieu ?, Communications, 87, pp. 5-16.

Bulot Thierry et Veschambre Vincent (Dirs.) (2006) Mots, traces et marques. Dimension spatiale et linguistique de la mémoire urbaine, Le Mesnil-sur-l'Estrée, L'Harmattan, $246 \mathrm{p}$.

Buttimer Anne and Seamon David (1980) The Human Experience of Space and Place, Londres, Croom Helm, 204 p. 
Capone Stefania (2010) Religions « en migration » : de l'étude des migrations internationales à l'approche transnationale, Autrepart, 56 (4), pp. 235-259.

Chevrier Marie-Hélène (2013) Pèlerinage et pratiques spatiales à Mexico et Lourdes. Entre familiarité et altérité, Carnets de géographes, 6, pp. 1-12.

Chiffoleau Sylvia (2003) Un champ à explorer : le rôle des pèlerinages dans les mobilités nationales, régionales et internationales du Moyen-Orient, Revue Européenne des Migrations Internationales, 19 (3), pp. 285-289.

Chiffoleau Sylvia et Madœuf Anna (Dirs.) (2005) Les pèlerinages au Maghreb et au Moyen-Orient. Espaces publics, espaces du public, Beyrouth, Presses de l'Ifpo, 406 p.

Collier John (1957) Photography in anthropology: a report on two experiments, American Anthropologist, 59, pp. 843-859.

Collins-Kreiner Noga, Kliot Nurit, Mansfeld Yoel and Sagi Keren (2006) Christian Tourism to the Holy Land. Pilgrimage during Security Crisis, Aldershot, Ashgate, 183 p.

Dardel Éric (1990 [1952]) L’homme et la terre. Nature de la réalité géographique, Paris, CTHS, 200 p.

Debarbieux Bernard (1995) Le lieu, le territoire et trois figures de rhétorique, Espace géographique, 24 (2), pp. 97-112.

Dejean Frédéric et Endelstein Lucine (2013) Approches spatiales des faits religieux, Carnets de géographes, 6, pp. 1-19.

Entrikin Nicholas (2003) Lieu, in Jacques Lévy et Michel Lussault Éds., Dictionnaire de la géographie et de l'espace des sociétés, Paris, Belin, pp. 1-5.

Feldman Jackie and Ron Amos (2011) American Holy Land: Orientalism, Disneyization, and the Evangelical Gaze, in Burkhard Schnepel, Gunnar Brands und Hanne Schönig, Orient - Orientalistik Orientalismus. Geschichte und Aktualität einer Debatte, Bielefeld, Transcript Verlag, pp. 151-176.

Foucault Michel (1984) Des espaces autres : Hétérotopies (1967), Architecture, Mouvement, Continuité, 5, pp. 46-49.

Goffman Erwin (1973) La mise en scène de la vie quotidienne, Paris, Éditions de Minuit, 256 p.

Halbwachs Maurice (2008 [1941]) La topographie légendaire des Évangiles en Terre sainte, Paris, PUF, $205 \mathrm{p}$.

Imbert Christophe, Dubucs Hadrien, Dureau Françoise et Giroud Matthieu (Dirs.) (2014) D'une métropole à l'autre. Pratiques urbaines et circulations dans l'espace européen, Paris, Armand Colin, $496 \mathrm{p}$.

Joseph Isaac (1997) Prises, réserves, épreuves, Communications, 65, pp. 131-142.

Joseph Isaac (1992) L'espace public comme lieu de l'action, Les Annales de la Recherche Urbaine, 57-58, pp. 1-9.

Kong Lily (2010) Global shifts, theoretical shifts: Changing geographies of religion, Progress in Human Geography, 34 (6), pp. 755-776.

Lahire Bernard (1998) L'homme pluriel. Les ressorts de l'action, Paris, Nathan, 272 p.

Lefebvre Henri (2000 [1974]) La production de l'espace, Paris, Anthropos, 485 p.

Lévy Jacques et Lussault Michel (Dirs.) (2000) Logiques de l'espace, esprit des lieux. Géographie à Cerisy, Paris, Belin, $351 \mathrm{p}$.

Massey Doreen and Jess Patricia (1995) A place in the World?, Oxford, The Open University, 256 p. 
Monnet Jérôme (1998) La symbolique des lieux : pour une géographie des relations entre espace, pouvoir et identité, Cybergeo, 56, pp. 1-10.

Pagès-El Karaoui Delphine (2005) Le mouled de Sayyid al-lBadawî à Tantâ : logiques spatiales et production d'une identité urbaine, in Sylvia Chiffoleau et Anna Madœuf Éds., Les pèlerinages au Maghreb et au Moyen-Orient, Beyrouth, Presses de l'Ifpo, pp. 237-264.

Park Chris (2004) Religion and geography, in John Hinnells Ed., Routledge Companion to the Study of Religion, Londres, Routledge, pp. 439-455.

Piette Albert (1996) Ethnographie de l'action. L'observation des détails, Paris, Métailié, 203 p.

Piveteau Jean-Luc (2010) Lieu et territoire : une consanguinité dialectique ?, Communications, 87, pp. 149-159.

Racine Jean-Bernard et Walther Olivier (2003) Géographie et religions : une approche territoriale du religieux et du sacré, L'information géographique, 67 (3), pp. 193-221.

Raulin Anne (2009) Minorités urbaines : des mutations conceptuelles en anthropologie, Revue Européenne des Migrations Internationales, 25 (3), pp. 33-51.

Relph Edward (1976) Place and placelessness, Londres, Pion, 156 p.

Retière Jean-Noël (2003) Autour de l'autochtonie. Réflexions sur la notion de capital populaire, Politix, 16 (63), pp. 121-143.

Ron Amos (2009) Towards a typological model of contemporary Christian travel, Journal of Heritage Tourism, 4 (4), pp. 287-297.

Rozenholc Caroline (2014) Sens du lieu, identifications et méditerranéité à Tel-Aviv et Marseille. Une proposition méthodologique pour l'analyse de la mondialisation des lieux en Méditerranée, Géographie et Cultures, 89-90, pp. 261-282.

Rozenholc Caroline (2010) Lire le lieu pour dire la ville. Florentin : une mise en perspective d'un quartier de Tel Aviv dans la mondialisation, Thèse de doctorat, Université de Poitiers, 546 p.

Schnell Izhak (2007) Conceptual Remarks for the Understanding of City and Border Systems in Global Reality, Geographica Helvetica, 62 (1), pp. 43-51.

Smith Neil (2004) Scale bending and the fate of the national, in Éric Sheppard and Robert McMaster Eds., Scale and geographic inquiry: nature, society, and method, Blackwell, Malden, pp. 192-212.

Thibaud Jean-Paul (2004) Une approche pragmatique des ambiances urbaines, in Pascal Amphoux, Grégoire Chelkoff et Jean-Paul Thibaud Éds., Ambiances en Débats, Grenoble, À la Croisée, pp. 145-158.

Trimbur Dominique (1998) Une présence française en Palestine. Notre-Dame de France, Bulletin du Centre de recherche français à Jérusalem, 3, pp. 32-58.

Trouillet Pierre-Yves (2015) Conclusions sur les articulations entre territoires et lieux de culte (avec un détour par l'hindouisme), Hypothèses, 1 (18), pp. 249-259.

Trouillet Pierre-Yves (2013) Pour une géographie sociale des faits religieux. L'exemple de l'hindouisme en pays Tamoul (Inde du Sud), Carnets de géographes, 6, pp. 1-23.

Yishai Yael (1999) Interest Politics in a Comparative Perspective: The (Ir)regularity of the Israeli Case, in David Levi-Faur, Gabriel Sheffer and David Voger Eds., Israel: The Dynamics of Change and Continuity, Londres, Frank Cass, pp. 73-86. 


\section{NOTES}

1. The term was coined by Prorok (2007) speaking of religiosity quoted by Kong (2010).

2. Aiming to eventually generalise the reflection on the role of international mobilities in the production of places, this research only addresses international tourist-religious mobilities. Local pilgrimages, although numerous within the Israeli-Palestinian space, are therefore not taken into account.

3. The construction of this park was extremely controversial. If its high cost (150 million dollars) was mostly financed by a creationist Christian association, it was also partially covered by the local authorities who saw an opportunity for tourist and economic development.

4. Cf. http://www.nazarethvillage.com/category/66/History-of-the-Village

5. Jerusalem's old town is less than 1 square kilometre and Israel is thirty times smaller than France.

6. These gardens are one of the seven places of pilgrimage in Galilee for the Baha'i religion, a religion born in Persia in the $19^{\text {th }}$ century but whose centre is now located in Israel.

7. Indeed, UNESCO documents emphasise the idea that for a century the city has grown alongside the Baha'i gardens. Cf. http://whc.unesco.org/fr/list/1220/documents/

8. Besides pilgrims and tourists, all the actors identified a priori as producers, in any capacity, of "places of mobility", will also be interviewed to understand everyone's role in the material and symbolic production of these places: pilgrims and religious tourists, local tourist guides, ministers and priests, shopkeepers, Jewish, Christian and Muslim inhabitants of the places visited, private and public developers of the places of pilgrimage, public managers.

\section{ABSTRACTS}

This research note aims to account for the theoretical and methodological paths emerging from an on-going research on the spatial effects of international religious mobility in the spaces towards which it converges. Initiated in the framework of a project of the MSH Paris Nord entitled "From memory to territories: questioning the production of places of mobility", this research focuses on the question of the places these touristic-religious mobilities concur to produce. It addresses both the practices these places generate and their material dimension. An exploratory field in Israel in 2016 has shown how, spreading out spatially, pilgrimages and religious tourism participate not only to produce places but also to produce different types of places. Three of these "places of mobility" have been identified: pilgrimage places, substitution places built to overcome the difficulty of accessing some holy places and theme parks. These observations raise the question of the processes, the actors and the modalities of production of these different types of places. It also raises the question of the circulation between these places and the circulation of these places themselves, across the Israeli-Palestinian national borders.

Cette note de recherche souhaite rendre compte des pistes théoriques et méthodologiques qui se dégagent d'une recherche en cours sur les effets spatiaux des mobilités religieuses internationales dans les espaces vers lesquels elles convergent. Initiée dans le cadre d'un projet de la MSH Paris Nord intitulé « De la mémoire aux territoires : interroger la fabrique des lieux de mobilité ", cette recherche porte plus précisément sur la question des lieux que ces mobilités touristico-religieuses concourent à produire en s'intéressant à la fois aux pratiques qu'ils 
suscitent et à la dimension matérielle de ces derniers. Un terrain exploratoire en 2016 en Israël un espace d'observation privilégié par l'omniprésence du religieux, sa diversité et ses effets particulièrement structurants sur l'espace - a montré comment, s'y déployant spatialement, pèlerinages et tourisme religieux participent non seulement à produire des lieux, mais également à produire différents types de lieux. Trois de ces « lieux de mobilité » ont été identifiés : des lieux de pèlerinage, des lieux de substitution construits pour pallier la difficulté d'accéder à certains lieux saints et, plus surprenant, des parcs à thème religieux. Ce constat pose la question des processus, des acteurs et des modalités de production de ces lieux de nature différente. Il pose également la question des circulations entre ces lieux et de la circulation des lieux eux-mêmes, c'est-à-dire de leur «translation » par-delà les frontières nationales d'un territoire israélopalestinien que l'on peut alors réinscrire dans l'espace des mobilités internationales et de la transnationalisation des pratiques et des lieux qu'il induit.

Esta nota de investigación está encaminada a informar sobre las vías teóricas y metodológicas que se desprenden de una investigación en curso sobre las incidencias espaciales de las movilidades religiosas internacionales en los espacios hacia las que convergen. Dicha investigación, que se inició en el marco de un proyecto de la MSH Paris Nord titulado: «De la memoria a los territorios: cuestiones sobre la fabricación de los lugares de movilidad», se centra más concretamente en el tema de los lugares que dichas movilidades turístico-religiosas contribuyen a producir, interesándose a la vez por las prácticas que esos lugares suscitan y por su producción material. Un trabajo sobre el terreno llevado a cabo en 2016 en Israel - país que constituye un espacio de observación privilegiado debido a la omnipresencia del factor religioso, la diversidad de éste y sus efectos especialmente estructurantes en el espacio - ha mostrado cómo las peregrinaciones y el turismo religioso, al desplegarse espacialmente, contribuyen no sólo a producir lugares sino también distintos tipos de lugar. Se han definido así tres «lugares de movilidad»: lugares de peregrinación, lugares de sustitución creados para enfrentarse con la dificultad de acceso a determinados lugares sagrados y, de modo un tanto sorprendente, parques temáticos de tipo religioso. Esto plantea la cuestión de los procesos, los agentes y las modalidades de producción de esos lugares de distinta índole. Plantea asimismo la cuestión de la circulación entre esos lugares y la de la circulación de los lugares en sí mismos, o sea de cómo se «trasladan» más allá de las fronteras de un territorio israelí-palestino que puede entonces ser reinstalado a su vez en el espacio de las movilidades internacionales, así como la de la transnacionalización de las prácticas y de los lugares que ello induce.

INDEX

Palabras claves: lugar, movilidades, turismo religioso, espacio israelí-palestino

Keywords: place, sense of place, mobilities, religious tourism, Israel-Palestine

Mots-clés: lieu, mobilités, tourisme religieux, espace israélo-palestinien

\section{AUTHORS}

\section{CAROLINE ROZENHOLC}

Geographer, Associate Professor, researcher at the CRH-UMR 7218 LAVUE, École nationale supérieure d'architecture de Paris-Val de Seine, 3-15 quai Panhard et Levassor, 75013 Paris; caroline.rozenholc@paris-valdeseine.archi.fr 